\title{
ANALYSING TALK
}




\title{
Other titles in the Studies in English Language series
}

\author{
A Course Book in English Grammar - Dennis \\ Freeborn \\ From Old English to Standard English - Dennis \\ Freeborn \\ Varieties of English, 2nd Edition - Dennis \\ Freeborn, with Peter French and David Langford \\ English Language Project Work - Christine \\ McDonald
}

\section{Series Standing Order}

If you would like to receive future titles in this series as they are published, you can make use of our standing order facility. To place a standing order please contact your bookseller or, in case of difficulty, write to us at the address below with your name and address and the name of the series. Please state with which title you wish to begin your standing order. (If you live outside the United Kingdom we may not have the rights for your area, in which case we will forward your order to the publisher concerned.)

Standing Order Service, Macmillan Distribution Ltd, Houndmills, Basingstoke, Hampshire, RG21 2XS, England 


\title{
ANALYSING TALK
}

\section{INVESTIGATING VERBAL INTERACTION IN ENGLISH}

\author{
David Langford
}

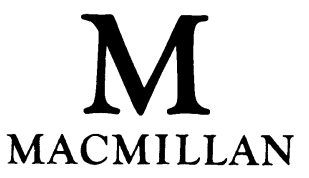


All rights reserved. No reproduction, copy or transmission of this publication may be made without written permission.

No paragraph of this publication may be reproduced, copied or transmitted save with written permission or in accordance with the provisions of the Copyright, Designs and Patents Act 1988, or under the terms of any licence permitting limited copying issued by the Copyright Licensing Agency, 90 Tottenham Court Road, London W1P 9HE.

Any person who does any unauthorised act in relation to this publication may be liable to criminal prosecution and civil claims for damages.

First published 1994 by

THE MACMILLAN PRESS LTD

Houndmills, Basingstoke, Hampshire RG21 2XS

and London

Companies and representatives

throughout the world

ISBN 978-0-333-42859-7

DOI 10.1007/978-1-349-23533-9

ISBN 978-1-349-23533-9 (eBook)

A catalogue record for this book is available from the British Library. 


\section{Contents}

Acknowledgements

Preface

ix

1 Talk and its place in our lives

1.1 Introduction

1.2 A profile of a language user

1.3 Language producers and language consumers

1.4 Writing, reading, speaking, listening

1.5 Language production and transmission writing

1.6 Language production and transmission speaking

1.7 Situation, participants and purposes

2 Imagining the organisation of talk

2.1 Introduction

2.2 Spoken verbal interaction

2.3 From guesses to observations to descriptions to discoveries

3 Transcribing the organisation of talk

3.1 Introduction

3.2 Slowing speech down 
3.3 Choosing a set of symbols 32

3.4 Beyond the words 36

3.5 Making a transcription 42

4 Seeing the organisation of talk 59

4.1 Introduction 59

4.2 Raised voices 60

4.3 Locating instances of a phenomenon 61

4.4 Sequential environments and interactional significance

4.5 The sequential environments and interactional significance of pauses

$5 \quad$ Taking turns in two-party talk 69

5.1 Introduction 69

5.2 The turn-taking problem 70

5.3 Dancing hands and careful gazes 71

5.4 Teleprinters, turn-taking and the deaf 73

5.5 Turn-taking and face-to-face interaction 83

5.5.1 Activities and turn-taking in the media interview

84

5.5.2 Activities and turn-taking in a domestic argument

$6 \quad$ Taking turns in multi-party talk 100

6.1 Introduction

100

6.2 Taking turns when there are more than two

101

7 Patterns in speech activities

119

7.1 Introduction

7.2 Talk management activities

120

7.3 Speech activities

8 Patterns in speech events 156

8.1 Introduction 156

8.2 Chats, conversations, discussions, talks 157

8.3 Participants, purposes and situations 
8.4 Boundaries and phases 159

8.5 Interactional tasks 160

8.6 Designing turns for interactional tasks 161

8.7 Telephone conversations 166

Appendix: what to do now 185

$\begin{array}{ll}\text { Index } & 186\end{array}$ 


\section{Acknowledgements}

The author and publishers are grateful to Dr John Lee of the University of Manchester and Dr Anthony Wootton of the University of York for kind permission to base transcriptions on their recordings.

Every effort has been made to trace all copyright-holders, but if any have been inadvertently overlooked the publishers will be pleased to make the necessary arrangement at the first opportunity. 


\section{Preface}

The study of language has traditionally focused on the grammatical, lexical and phonological features of particular languages or language varieties. It is in these areas that systematic patterning has been most evident and describable. It was assumed that the use of language in verbal interaction was not subject to predictable patterning. However, the investigation of how people interact verbally with one another has become over recent years an increasingly important part of language study. We do make sense of each other as a matter of routine in all sorts of interaction and in making sense of each other we go beyond the words used. The investigation of how people interact verbally amounts to the investigation of the ways in which we go beyond the words used.

This book sets out to provide beginning students of language use with a guide to setting about their own descriptions of how speakers in particular interactions have behaved in systematic ways and made sense of each others' behaviour. Records of interaction that have been collected by myself, colleagues and students and used in teaching form the basic data of the guide. Transcriptions have been made of material privately recorded or publicly broadcast. Care has been taken to acknowledge the original data sources but given the nature of the material this has not always been possible.

The general analytical approach adopted is derived from the work of conversation analysts such as Paul Drew, Anthony 
Wooton, Gail Jefferson, Anita Pomerantz and Emanuel Schegloff. However, the book has concentrated on practical approaches to data analysis rather than on the substantive findings of researchers in the field. The aim has been to demonstrate that there is exciting research potential in any record of conversation and that the skills needed for original description can be developed by individuals working at quite different levels of sophistication in language study.

I do hope that the reading of this book will begin to bring into sharper focus the richness and complexity of everyday verbal interaction.

For those who wish to familiarise themselves with current research, other works have been more concerned to reflect the range of investigations into verbal interaction that have been informed by the approach presented here. In particular the reader's attention is drawn to Robert E. Nofsinger's Everyday Conversation (1991) for an accessible recent summary.

DAVID LANGFORD 